\title{
IMPLEMENTASI WHOLE LANGUAGE APPROACH SEBAGAI PENGEMBANGAN MODEL PEMBELAJARAN BERBAHASA AWAL ANAK USIA 5-6 TAHUN DI PAUD NON FORMAL
}

\author{
Nehru Meha dan Adiyati Fathu Roshonah \\ Universitas Muhammadiyah Jakarta \\ n3hru@yahoo.com
}

\begin{abstract}
This study was conducted to implementa holistic approach to language (whole language approach) as the development of early language learning model of children aged 5-6 years in Non-Formal early childhood. As commonly known, ordinary people generally narrows aspects of language learning on only one small part of language development include reading and writing. On the other hand, the whole language approach has not been widely known specially applied nearly language learning in early childhood Non-Formal, but if implemented correctly and consistently, this approach is able to foster interest in literacy children naturally and fun. Whole language has been implemented nearly childhood language learning in developed countries that have a high interest in literacy. This study used action research methods by giving the action in each cycle from planning, action, observation, and reflection. This research was carried out in Non-Formal Childhood Education "Mawar" in South Tangerang January to July 2014. The subjects of this study consisted of 10 children aged 5-6 years were selected based on the observation of pre-cycle.

The results of observations processed through data analysis techniques with descriptive statistics, namely to find the percentage and the average value of the initial improvements in language skills acquired through observation, interviews and discussions, as well as document review. The results showed that the implementation of the whole language approach that include simmertion, demonstration, expectation, responsibility, employment, approximation, feedback can improve early reading skills of young children. Based on pre-cycle observations initially beginning literacy percentage of $30.25 \%$ is still a child. In the first cycle after the action as much as 7 times the meeting obtained by an increase in the percentage amounted to $85.50 \%$. Based on these data showed an increase in the percentage of literacy of the observation of pre-cycle by $55.25 \%$. The implications of this study are expected to approach whole language can be used as the development of early language learning model early childhood 5-6 years in Non-Formal early childhood, because it is natural and fun and developmentally age children.
\end{abstract}

Keywords: Early childhood, early language ability, whole language approach

\begin{abstract}
ABSTRAK
Penelitian ini dilakukan untuk mengimplementasikan pendekatan bahasa holistik (whole language approach) sebagai pengembangan model pembelajaran berbahasa awal anak usia 5-6 tahun di PAUD Non Formal. Sebagaimana lazim diketahui, masyarakat awam umumnya menyempitkan aspek pembelajaran berbahasa hanya pada salah satu bagian kecil perkembangan bahasa meliputi membaca dan menulis. Di sisi lain, pendekatan whole language belum banyak diketahui apalagi diterapkan di dalam pembelajaran berbahasa awal anak usia dini di PAUD Non Formal, padahal apabila diimplementasikan secara benar dan konsisten pendekatan ini mampu menumbuhkan minat literasi (keaksaraan) anak secara alamiah dan menyenangkan. Whole
\end{abstract}


language telah diterapkan dalam pembelajaran berbahasa anak usia dini di negara-negara maju yang memiliki minat literasi tinggi.

Penelitian ini menggunakan metode penelitian tindakan (action research) dengan memberikan tindakan pada setiap siklus mulai dari perencanaan, tindakan, pengamatan, dan refleksi. Penelitian ini dilaksanakan di PAUD Non Formal Mawar Tangerang Selatan pada bulan Januari sampai Juli 2014. Subyek penelitian ini terdiri dari 10 orang anak usia 5-6 tahun yang dipilih berdasar hasil observasi pra siklus. Hasil observasi diolah melalui tekhnik analisis data dengan statistik deskriptif, yaitu mencari persentase dan nilai rata-rata peningkatan kemampuan berbahasa awal yang diperoleh melalui observasi, interview dan diskusi, serta kajian dokumen. Hasil penelitian menunjukkan bahwa implementasi pendekatan whole language yang meliputi immertion, demonstration, expectation, responsibility, employment, approximation, and feedback dapat meningkatkan kemampuan membaca awal anak usia dini. Berdasarkan observasi pada pra siklus pada awalnya persentase kemampuan membaca permulaan anak masih sebesar 30,25\%. Pada siklus I setelah dilakukan tindakan sebanyak 7 kali pertemuan diperoleh peningkatan persentase menjadi sebesar 85,50\%. Berdasarkan data tersebut menunjukkan peningkatan persentase kemampuan membaca dari hasil observasi pra siklus sebesar 55,25\%. Implikasi dari penelitian ini diharapkan pendekatan whole language dapat dijadikan sebagai pengembangan model pembelajaran berbahasa awal anak usia dini 5-6 tahun di PAUD Non Formal, karena sifatnya yang alamiah dan menyenangkan serta seusia dengan tahapan perkembangan anak.

Kata Kunci: Anak usia dini, kemampuan berbahasa awal, pendekatan whole language

Pendirian lembaga PAUD Non Formal yang berasal dari inisiatif masyarakat merupakan fakta menarik yang patut disyukuri. Keluarga Indonesia yang memiliki anak usia dini terutama dari kalangan ekonomi menengah ke bawah namun memiliki akses yang minim dalam hal pendidikan anak usia dini diharapkan memperoleh kemanfaatan optimal dari keberadaan layanan dimaksud. Anak usia dini yang mendapatkan stimulasi sesuai usia dan tahapan perkembangannya, kelak akan menjadi anak-anak yang melejit potensinya secara alami dan mengagumkan di usia selanjutnya. Namun sebagaimana kita ketahui dengan maraknya keberadaan pendirian layanan PAUD Non Formal masih belum diikuti dengan kompetensi dan kualitas tenaga pendidiknya. Pendidik PAUD Non Formal tersebut umumnya berasal dari para Kader PKK dan Kader Posyandu atau para ibu rumah tangga yang direkrut secara 'serabutan' atau apa adanya. Umumnya para pendidik PAUD Non Formal ini bukan berlatar belakang pendidikan anak usia dini, atau memiliki keterbatasan latar belakang pendidikan anak. Karena minimnya dasar-dasar pengetahuan mereka tentang anak usia dini inilah sehingga masih banyak dijumpai layanan PAUD Non Formal yang belum dan bahkan kurang memahami dasar-dasar perkembangan anak yang mengakibatkan kesulitan dalam mengimplementasikan proses pembelajaran yang sesuai dengan minat dan karakter anak usia dini. Padahal proses pembelajaran pada peserta didik akan lebih berhasil jika disesuaikan dengan usia dan tahapan perkembangan anak serta melihat kesiapan dan kematangan anak usia dini yang diasuhnya.

Kekurangtepatan penanganan anak usia dini yang disebabkan oleh keterbatasan kompetensi pendidik merupakan suatu hal yang harus kita cermati bersama. Para pendidik PAUD Non Formal kadangkala mengajar anak usia dini semata permintaan orang tua dan memenuhi pangsa pasar seperti target-target baca, tulis atau berhitung tanpa mempertimbangkan kesiapan dan kematangan anak usia dini yang ada dalam tanggung jawabnya. Guru menjejalkan pelajaran untuk anak usia dini layaknya pembelajaran untuk anak usia Sekolah Dasar tanpa mempertimbangkan 
prinsip pembelajaran anak usia dini yakni belajar sambil bermain. Di sisi lain para orang tua sendiri bangga menyekolahkan anaknya di layanan PAUD Non Formal tersebut karena di usia yang relatif sangat muda anak-anak mereka sudah memiliki kemampuan skolastik berupa calistung.

Keterbatasan kompetensi yang dimiliki oleh para pendidik PAUD Non Formal inilah yang selayaknya menjadi perhatian dan tanggung jawab para stakeholders pendidikan sehingga ketidakberuntungan sosial dan ekonomi bisa disiasati dengan mencari solusi yang tepat dan sesuai sasaran.

Perkembangan anak usia dini berlangsung secara holistik dan komprehensif. Salah satu aspek perkembangan anak yang difokuskan dalam pendidikan anak usia dini adalah aspek perkembangan bahasa. Kemampuan berbahasa awal untuk anak usia dini terutama difokuskan pada aspek menyimak (listening), berbicara (speaking), membaca awal (pre-reading) dan menulis awal (pre-writing). Seluruh aspek kemampuan berbahasa awal untuk anak usia dini ini sesungguhnya dapat dikembangkan dengan metode whole language dalam pembelajaran. Whole language telah banyak diimplementasikan dalam dunia pendidikan di banyak negara maju, yang diyakini memberi dampak signifikan terhadap perkembangan berbahasa anak.

Berawal dari pengamatan sederhana di beberapa layanan PAUD Non Formal, whole language ternyata belum banyak diketahui apalagi dipraktekkan, hal ini karena keterbatasan informasi dan kompetensi para pendidik serta minimnya motivasi yang mereka miliki. Sebagaimana lazim diketahui, masyarakat awam umumnya menyempitkan aspek kemampuan berbahasa ini pada salah satu bagian kecil meliputi membaca dan menulis, atau calistung semata.

Menemukan model pengembangan bahasa awal menggunakan metode whole language untuk anak usia dini menjadi sesuatu yang penting diketahui khususnya untuk pendidik PAUD Non Formal, terlebih mengingat obsesi sebagian orang tua anak usia dini tanpa sadar menggegas anak segera berkemampuan membaca dan menulis untuk kebutuhan praktis mengatasi kendala pembelajaran di tingkat SD (Sekolah Dasar). Padahal pembelajaran 'calistung' di usia dini jelas berbeda dengan di SD. Anak usia dini yang digegas mungkin akan cepat tumbuh dan cepat mampu, namun karena tidak diikuti oleh kesukaan, akibatnya potensi minat bacanya rendah, karena kesalahan proses pembelajaran literasinya.

Pemahaman yang benar dan komprehensif tentang whole language di PAUD Non Formal sangat urgen diketahui, selanjutnya diimplementasikan agar menjadi salah satu solusi bagi rendahnya minat literasi anak-anak Indonesia.

Berdasarkan latar belakang tersebut, maka fokus masalah dalam penelitian ini adalah bagaimana Model Pengembangan Kemampuan Berbahasa Awal Pada Anak Usia Dini Dengan Pendekatan Whole Language di PAUD Non Formal (Action Research di PAUD Mawar Tangerang Selatan).

Merujuk pada fokus masalah di atas, rumusan masalah dalam penelitian ini:

1. Apakah model pendekatan whole language dapat meningkatkan kemampuan membaca awal anak usia dini pada layanan PAUD Non Formal Mawar Tangerang Selatan?

2. Bagaimana langkah-langkah implementasi whole language approach dalam pengembangan model berbahasa awal untuk anak usia dini di PAUD Non Formal Mawar Tangerang Selatan?

Manusia sebagai mahluk hidup akan mengalami fase pertumbuhan dan perkembangan. Pertumbuhan dalam aspek fisik lebih kepada perubahan yang bersifat penambahan, misalnya bertambah tinggi atau bertambah besar fostur tubuh, semakin panjang rambut, kuku dan organ tubuh lainnya yang mengalami pertumbuhan. Perkembangan lebih kepada perubahan pada aspek psikis yang berlangsung secara terus menerus. 
Fase pertumbuhan dan perkembangan akan senantiasa saling terkait antara satu dengan yang lainnya. Sebagai contoh perkembangan kemampuan berbahasa didukung oleh pertumbuhan organ bicara begitu juga dengan yang lainnya. Pertumbuhan dan perkembangan yang terjadi pada manusia diantaranya anak usia dini senantiasa akan membutuhkan rangsangan atau stimulasi dari lingkungan yang dalam hal ini orang dewasa merupakan lingkungan luar yang paling dekat dengan anak.

Berdasarkan beberapa pandangan tentang perkembangan menyatakan bahwa perkembangan adalah proses perubahan-perubahan yang dialami individu menuju tingkat pendewasaan atau kematangannya yang berlangsung sejak masa konsepsi sampai individu itu meninggal. Perubahan tersebut berlangsung secara sistematis, progresif dan berkesinambungan, baik menyangkut fisik maupun psikis.

Aspek perkembangan bahasa mencakup kemampuan membaca dan menyimak yang bersifat reseptif-aktif dan kemampuan menulis serta berbicara yang bersifat produktif. Sehubungan dengan perkembangan kemampuan keaksaraan pada masa usia dini, International Reading Association (1985) menyatakan beberapa hal antara lain bahwa kemampuan keaksaraan dipelajari sejak masa bayi dan anak-anak perlu ditenggelamkan dalam lingkungan keaksaraan yang kaya, serta belajar memerlukan lingkungan yang mendukung dan membangun perasaan positif tentang aktivitas literasi. Selain itu orang dewasa yang berada di sekitar anak harus menjadi model perilaku keaksaraan yang mencontohkan dan menunjukkan minat yang besar terhadap buku dan bahan cetakan. Pengalaman keaksaraan dini harus bermakna dan konkret serta secara aktif melibatkan anak dan program pengembangan kemampuan keaksaraan harus berfokus pada pendekatan holistik, dengan menggunakan pengalaman-pengalaman fungsional yang mencakup kegiatan berbicara, menyimak, menulis, dan membaca (Morrow, 1993: 3).

Perkembangan bahasa anak usia dini meningkat pesat seiring dengan besarnya keinginan untuk banyak bicara, bertanya, dan menjalin komunikasi dengan lingkungannya termasuk temanteman dan orang tuanya. Perkembangan bahasa ditandai dengan bertambahnya jumlah kosa kata dan meningkatnya keterampilan berbicara. Anak menggunakan bahasa untuk mengekspresikan keinginannya.

Perkembangan bahasa anak masih bersifat egosentris. Ketika anak berbicara, anak berharap ucapannya dapat didengar dan dimengerti oleh orang lain. Anak juga sangat suka membicarakan dirinya sendiri, keluarganya, dan minat atau kesukaannya. Perilaku egosentris ini lambat laun akan berkurang saat anak memasuki masa akhir anak-anak.

Peningkatan kemampuan berbahasa dan bertambahnya kosa kata semakin memudahkan anak dalam menjalin komunikasi dengan teman sebayanya. Pada usia 5-6 tahun, perkembangan bahasa anak sudah kompleks, menggunakan kalimat yang benar, menggunakan kata ganti; masa lampau, masa kini, dan kata kerja untuk masa yang akan datang; rata-rata panjang kalimat pada setiap percakapan mencapai 6-8 kata. Kosa kata: pengguanaan kira-kira 2.500 kata, memahami manusia 6.000 kata serta menanggapi sampai 25.000 kata (Woolfolk, 2009: 42).

Anak usia dini mampu mengekspresikan keinginannya dengan ungkapan kalimat yang lebih jelas sehingga anak tidak mengalami kesulitan dalam berkomunikasi, selain itu anak usia ini senang menceritakan pengalamannya kepada orang lain. Selanjutnya, ketertarikannya membaca buku disebabkan karena anak usia ini sudah mampu mengerti simbol gambar.

Jika dideskripsikan dari uraian-uraian tersebut maka perkembangan bahasa anak usia dini berkembang sangat pesat. Perbendaharaan dan kosa kata anak mulai bertambah dan berkembang, sehingga memudahkan dan membantu anak untuk berkomunikasi dengan anak seusianya maupun 
dengan orang dewasa. Anak pada masa ini sudah mengenal kata-kata dan semakin memiliki rasa ingin tahu yang besar sehingga penting bagi pendidik untuk mendorong anak sering bertanya. Bahasa anak mulai memasuki bahasa sosial, dimana anak sering melakukan percakapan dengan teman sebaya dan lingkungan di sekitarnya.

Selain itu dapat dideskripsikan bahwa perkembangan bahasa, khususnya membaca, pada anak usia dini berada dalam tahap membaca permulaan. Simbol-simbol abstrak selain huruf dan kata, seperti mimik, gambar, atau citra mental, akan bermakna bagi anak usia ini. Banyak cara yang dapat digunakan dalam mendukung pengembangan berbahasa anak, salah satunya adalah mengenalkan anak dengan dunia membaca.

Sebelum mengajarkan pada anak, guru harus memahami terlebih dahulu bahwa kegiatan membaca memerlukan kemampuan yang lebih sederhana, yaitu: (1) kemampuan mengenali bunyi, (2) kemampuan mengenali benda, (3) kemampuan mengenal bentuk, (4) kemampuan mengenal simbol/lambang, (5) kemampuan mengasosiasikan bentuk huruf/tulisan dan bunyi, (6) kemampuan mengenali huruf dan suku kata untuk menggabungkan menjadi kata. (Departemen Pendidikan Nasional, 2009;29-31).

Saat anak telah mencapai atau memiliki keterampilan yang terakhir, maka pada tahap tersebut anak akan siap mulai membaca. Jika anak telah memiliki kesiapan membaca maka pembelajaran membaca permulaan dapat mulai dilakukan. Dalam kurikulum 2004, indikator perkembangan bahasa anak usia dini, diantaranya: (1) membedakan dan menirukan kembali bunyi/suara tertentu, (2) mendengarkan dan menceritakan kembali cerita secara urut, (3) membuat gambar dan menceritakan isi gambar dengan beberapa coretan/tulisan yang sudah berbentuk huruf/kata, (4) bercerita tentang gambar yang disediakan atau yang dibuat sendiri dengan urut dan bahasa yang jelas, (5) membaca buku menceritakan isi buku dengan menunjuk beberapa kata yang dikenalnya, (6) menghubungkan dan menyebutkan tulisan sederhana dengan simbol yang melambangkannya, (7) mengurutkan dan menceritakan isi gambar seri (4-6 gambar), (8) melakukan 3-5 perintah secara berurutan dengan benar, (9) membedakan kata-kata yang mempunyai suku kata awal yang sama. (Departemen Pendidikan Nasional; 2009: 29-31).

Whole language berakar pada teori perkembangan John Dewey, pemikiran Vygotsky tentang konteks sosial, teori perkembangan kognitif Piaget, dan termasuk juga teori bahasa Kenneth Goodman. Whole language merupakan pendekatan pembelajaran bahasa yang berbeda dari pendekatan lain, yang memiliki perhatian dan konsistensi terhadap pemahaman bagaimana anak belajar (Weaver, 2003:3). Whole language menyediakan fasilitas belajar yang didasarkan pada pemahaman bahwa anak belajar secara alami dalam suasana yang menyenangkan, jauh dari paksaan, dan tanpa terus menerus memberikan kritik pada anak. Menurut Eisele dalam Weaver, whole language adalah sebuah pemikiran tentang bagaimana anak belajar bahasa, baik lisan maupun tulisan (Weaver, 2003: 3). Anak belajar berbicara, mendengarkan, membaca, dan menulis sesuai dengan perkembangannya. Kemampuan berbicara dan mendengarkan anak, didapat dari hasil interaksi anak dengan lingkungan dan orang-orang sekitar. Kemampuan membaca dan menulis, dirangsang dengan menciptakan lingkungan yang penuh dengan tulisan di tempat-tempat yang sering didatangi anak. Dengan demikian secara tidak sadar dan alami anak telah belajar bahasa.

Pendekatan whole language beranjak dari pernyataan Dewey tentang hakikat siswa, yakni siswa memiliki kekuatan, kesanggupan, dan keinginan untuk belajar. Siswa akan menjadi pribadi kreatif yang mampu menyusun, menciptakan dan menemukan pemecahan terhadap berbagai persoalan secara aktif jika mereka diberi kesempatan untuk melakukan aktivitas tersebut selaras 
dengan kemampuannya. Whole Language adalah satu pendekatan pembelajaran, yang secara alamiah diyakini mampu membantu perkembangan bahasa anak-anak di sekolah atau di kelas. Istilah Whole Language telah dikenal sebagai salah satu pendekatan pembelajaran, sebuah sistem kepercayaan tentang sifat pembelajaran dan bagaimana hal itu dapat dipupuk di kelas dan sekolah (Weaver, 1990: 3). Pendekatan ini secara luas diyakini dapat menyediakan lingkungan yang bermakna bagi peserta didik untuk belajar.

Pendekatan terpadu dalam pembelajaran bahasa dilandasi pandangan bahasa holistik (whole language) yang memperlakukan bahasa sebagai sesuatu yang bulat dan utuh. Pendekatan whole language beranjak dari pernyataan Dewey tentang hakikat siswa, yakni siswa memiliki kekuatan, kesanggupan, dan keinginan untuk belajar. Whole language (Weaver, 2003: 3) adalah satu pendekatan pembelajaran secara alamiah diyakini mampu membantu perkembangan bahasa anakanak di sekolah atau di kelas. Istilah whole language telah dikenal sebagai salah satu pendekatan pembelajaran, sebuah sistem kepercayaan tentang sifat pembelajaran dan bagaimana hal itu dapat dipupuk di kelas dan sekolah. Pendekatan ini secara luas diyakini dapat menyediakan lingkungan yang bermakna bagi peserta didik.

Kenneth Goodman menguraikan tentang teori-teori belajar yang menjadi dasar pendekatan whole language, menyatakan bahwa pembelajaran bahasa akan menjadi mudah ketika dilaksanakan secara utuh, nyata, dan relevan, masuk akal (makes sense), fungsional, dikaitkan dengan konteks yang digunakan dan ketika siswa memilih untuk menggunakannya (Goodman, 1986: 26). Pendekatan whole language berusaha untuk memberdayakan para guru dan siswa, yang dikembangkan berdasarkan hasil penelitian yang menyatakan bahwa belajar bahasa harus alami. Akan lebih mudah jika siswa terlibat dalam kegiatan penggunaan bahasa yang nyata.

Pendekatan whole Language didasari oleh paham constructivism yang menyatakan bahwa siswa membentuk sendiri pengetahuannya melalui peran aktifnya dalam belajar secara utuh dan terpadu. Fungsi guru dalam kelas whole language berubah dari desiminator informasi menjadi fasilitator. Dalam kelas whole language siswa terlibat secara aktif dalam pembelajaran yang membantu mengembangkan rasa tanggung jawab dan tidak tergantung. Siswa terlibat dalam kegiatan kelompok kecil atau kegiatan individual. Di kelas whole language siswa berani mengambil risiko dan bebas bereksperimen. Guru di kelas whole language menyediakan kegiatan belajar dalam berbagai tingkat kemampuan sehingga semua siswa dapat berhasil. Di kelas whole language siswa mendapat umpan balik (feedback) positif dari guru maupun temannya. Pemberian feed-back dilakukan dengan segera, sesuai dengan komponen pendekatan whole language (Hairuddin, 2007: 2-19).

Menurut Routman dan Frosse dalam Yarmi (2008) ada delapan komponen Whole Language yaitu: (1) Reading Aloud, yakni kegiatan membaca yang dilakukan oleh guru untuk siswanya. Guru dapat menggunakan bacaan yang terdapat dalam buku teks atau buku cerita lainnya. Buku tersebut dibacakan dengan suara keras dan intonasi yang baik sehingga setiap siswa dapat mendengarkan dan menikmati cerita. Manfaatnya adalah meningkatkan minat baca pada anak, (2) Journal Writing, yang merupakan sarana yang aman bagi siswa untuk mengungkapkan perasaannya, (3) Sustained Silent Reading, yakni kegiatan membaca dalam hati yang dilakukan oleh siswa. Dalam kegiatan ini siswa diberi kesempatan untuk memilih sendiri buku atau materi yang akan dibacanya, sesuai dengan kemampuannya sehingga mereka dapat menyelesaikan membaca bacaan tersebut dengan baik, (4) Shared Reading, yakni kegiatan bersama antara guru dan siswa, dimana setiap orang mempunyai buku yang sedang dibacanya. Bisa dilakukan dengan cara guru membaca dan siswa mengikutinya, atau guru membaca dan siswa menyimak sambil melihat bacaan yang tertera pada 
buku, atau siswa membaca bergiliran, (5) Guided Reading atau membaca terbimbing dimana guru menjadi pengamat dan fasilitator. Dalam membaca terbimbing penekanan bukan dalam membaca itu sendiri tetapi lebih kepada membaca untuk pemahaman. Dalam pembelajaran melalui Guided Reading semua siswa membaca dan mendiskusikan buku yang sama, (6) Guided Writing (menulis terbimbing) dimana guru berperan sebagai fasilitator, membantu siswa menemukan apa yang ingin ditulisnya dan bagaimana menulisnya dengan jelas, sistematis dan menarik, (7) Independent Reading (membaca bebas) adalah kegiatan membaca, dimana siswa berkesempatan untuk menentukan sendiri materi yang akan dibacanya. Siswa bertanggung jawab terhadap bacaan yang dipilihnya sehingga peran guru berubah dari pemrakarsa, model dan pemberi tuntunan menjadi seorang pengamat, fasilitator dan pemberi respon, (8) Independent Writing, yaitu menulis bebas bertujuan untuk meningkatkan kemampuan menulis, meningkatkan kebiasaan menulis, dan meningkatkan kemampuan berfikir kritis dalam menulis (Yarmi, 2008: 9-13).

Berkaitan dengan pengkondisian kelas, pendekatan whole language mempersyaratkan penataan kelas yang menarik minat anak pada bahasa. Yeager (1999) menyebutkan bahwa kelas whole language memiliki beberapa area antara The Conference Centre, The Library, The Publishing Centre, Author's Centre, The Reading Centre, dan The Writing Centre (Yeager, 1991: 4).

\section{METODE}

Subjek dalam penelitian ini adalah peserta didik usia 3-4 tahun yang berjumlah 10 orang terdiri dari 5 orang putra dan 5 orang putri. Sementara partisipan yang terlibat adalah peneliti dan satu orang anggota, bersama dengan 3 orang guru PAUD Non Formal Mawar Tangerang Selatan sebagai kolaborator. Metode penelitian yang digunakan adalah metode action research atau penelitian tindakan kelas (PTK), yakni form of self reflective inquiry undertaken by particypants (teacher, student or principals, for example) in social (including educational) situasion in order to improve the rationality and justice of (a) their own social or educational practices, (b) their understanding of these practices are carried out (Mulyasa, 2009-15).

Disain intervensi tindakan yang digunakan dalam penelitian ini adalah model spiral dari Kemmis dan Taggart. Rancangan setiap siklus terdiri dari perencanaan kegiatan, metode yang akan digunakan dalam tindakan (planning), pengamatan dilakukan oleh peneliti dan kolaborator terhadap kegiatan tindakan dan kemampuan anak (observing), serta refleksi (reflection). Penelitian dimulai dari tahap perencanaan kemudian melakukan tindakan dan pengamatan. Refleksi diri merupakan dasar untuk strategi pemecahan masalah dan dasar untuk melakukan perencanaan tindakan lanjutan pada siklus selanjutnya.

Penelitian ini dikatakan berhasil apabila terjadi peningkatan prosentase minimal sebesar 20\% sebagaimana rekomendasi dari Mills (Mills, 2003: 101). Pengumpulan data yang digunakan dalam penelitian tindakan ini adalah non tes, yakni menggunakan pengamatan (observation).

Tahapan dalam pengisian lembar observasi, pengamat memberikan data cheklist (V) pada skala kemunculan kemampuan membaca permulaan yang disesuaikan. Model yang digunakan adalah model skala Likert. Model ini digunakan untuk menilai sikap atau tingkah laku yang diinginkan oleh para peneliti selain itu untuk mengukur sikap seseorang terhadap objek-objek tertentu. Setiap butir indikator diberikan tanda cheklist (V) pada kolom konsisten (K), berkembang (B), mulai muncul (MM), dan belum muncul (BM). Setiap butir indikator diberi skor 1-4 sesuai tingkat jawabannya. 
Tabel 1. Skala kemunculan kemampuan membaca permulaan

\begin{tabular}{lc}
\hline Pilihan Jawaban & Skor \\
\hline Konsisten & 4 \\
Berkembang & 3 \\
Mulai Muncul & 2 \\
Belum Muncul & 1 \\
\hline
\end{tabular}

Penilaian yang diberikan memiliki beberapa ketentuan yang telah disepakati bersama antara peneliti dan kolaborator, yaitu:

Tabel 2. Kriteria Intensitas Skala Kemunculan

\begin{tabular}{ll}
\hline Skala & Ketentuan \\
\hline Konsisten & Tugas dilakukan anak dengan tepat, benar, lancar dan lengkap tanpa bantuan \\
Berkembang & Tugas dilakukan anak dengan benar, dan lengkap tanpa bantuan \\
Mulai Muncul & Tugas dilakukan anak benar walaupun kurang lengkap dan dengan bantuan \\
Belum Muncul & Tugas dilakukan anak salah meskipun dengan bantuan \\
\hline
\end{tabular}

Membaca permulaan adalah kemampuan dasar berbahasa anak yang berkaitan dengan proses menterjemahkan simbol tulisan atau huruf serta gambar kedalam kata-kata lisan, yang prosesnya terdiri dari sensori visual dan perseptual.Adapun whole language adalah salah satu metode pembelajaran kemampuan berbahasa pada anak yang alami, menekankan pada lingkungan belajar yang kaya bahasa dan tulisan, pembelajaran yang aktif dan interaktif, berpusat pada siswa dalam rangka mengembangkan kemampuan menulis, membaca, berbicara dan mendengar.

Membaca permulaan adalah skor yang diperoleh dari hasil observasi kemampuan membaca yang berkaitan dengan proses menterjemahkan simbol tulisan atau huruf serta gambar ke dalam kata-kata lisan, yang prosesnya terdiri dari sensori visual dan perseptual. Adapun Whole language adalah data yang diperoleh dari hasil observasi metode pembelajaran kemampuan berbahasa pada anak yang menekankan pada lingkungan belajar yang kaya bahasa dan tulisan, pembelajaran yang aktif dan interaktif, berpusat pada siswa dalam rangka mengembangkan kemampuan menulis, membaca, berbicara, dan mendengar.

Instrumen peneliti yang digunakan berupa pedoman observasi kemampuan membaca dan pedoman pembelajaran whole language. Adapun instrumen kemampuan membaca permulaan untuk mengetahui sejauh mana kemampuan membaca permulaan siswa adalah dengan melakukan pengamatan kemampuan membaca permulaan anak selama proses permainan berlangsung. Adapun instrumen pedoman pembelajaran whole language dijadikan acuan atau pedoman pembelajaran dalam memberikan tindakan saat proses penelitian.

Tabel 3. Kisi-kisi \& Penyebaran Butir Instrumen Kemampuan Membaca Awal

\begin{tabular}{|c|c|c|c|c|}
\hline Variabel & Aspek & Indikator & $\begin{array}{c}\text { Butir } \\
\text { Penyebaran }\end{array}$ & $\mathrm{Jm}$ \\
\hline Membaca & Decoding (Memberikan tanda & Mengetahui simbol-simbol grafi (huruf atau kata) & 4 & 1 \\
\hline \multirow[t]{5}{*}{ Awal } & pada huruf atau kata) & Menyebutkan ya & 1,3 & 2 \\
\hline & $\begin{array}{l}\text { Analogi (Mensejajar kan simbol } \\
\text { huruf atau kata) }\end{array}$ & $\begin{array}{l}\text { Menghubungkan tulisan sederhana dengan simbol yang } \\
\text { melambangkannya }\end{array}$ & 2,6 & 2 \\
\hline & & $\begin{array}{l}\text { Membuat kattulisan sederhana melalui simbol yang } \\
\text { melambangkanna dari huruf awal yg sudah ditentukan }\end{array}$ & 5,7 & 2 \\
\hline & Prediction (Menafsirkan bentuk & Membentuk kata sederhana dan suku kata & 8,9 & 2 \\
\hline & huruf atau kata) & Menyebutkan kata-kata yang mempunyai suku kata yg sama & 10 & 1 \\
\hline Jumlah & & & & 10 \\
\hline
\end{tabular}


Tabel 4. Pedoman Pembelajaran Berbahasa Awal Pendekatan Whole Language

\begin{tabular}{|c|c|}
\hline ASPEK & INDIKATOR \\
\hline Pendekatan & 1. Immersion \\
\hline Pembelajaran & (menyediakan lingkungan yang \\
\hline $\begin{array}{l}\text { Whole } \\
\text { Language }\end{array}$ & \\
\hline
\end{tabular}

2. Demonstration (anak belajar melalui model)

3. Expectation

(anak belajar sesuai tahap perkembangannya)

\section{Responsibility} (anak berbagi pengalaman sekaligus tanggung jawab terhadap proses belajar mereka sendiri)

\section{Employment}

(anak terlibat aktif dalam belajar dan bekerja yang nyata dan bertujuan)

6. Approximation (anak distimulasi dan diberi kesempatan bereksperimen)
1. Menyediakan perpustakaan kelas

2. Menyediakan berbagai sumber bacaan (buku cerita bergambar, buku alphabet, majalah anak-anak, koran) di pojok baca/perpustakaan

3. Memberi label pada semua benda di kelas

4. Membuat papan buletin

5. Menggantungkan huruf-huruf, alphabet

6. Menempelkan gambar benda/hewan dari huruf $a-z$

1. Guru membacakan buku cerita pada anak.

2. Anak mendengarkan cerita anak-anak dari kaset

3. Anak-anak menonton VCD berisi cerita anak-anak

4. Guru memperlihatkan dan menunjukkan gambar beserta tulisannya

5. Anak menceritakan kembali isi cerita dan menuliskan tokoh-tokoh yang ada dalam cerita

6. Guru menunjukan, menyebutkan, menuliskan huruf awal pada sebuah kata, anak menyebutkan sebanyaknya kata dari huruf awal yang ditulis oleh guru

1. Mendesain ruang belajar yang menyenangkan (penuh gambar dan warna, serta tulisan sederhana)

2. Menyediakan alat permainan edukatif yang merangsang anak untuk belajar sambil bermain, seperti kartu bergambar, balok, plastisin, lego, boneka tangan dan bak pasir)

3. Menyediakan buku-buku cerita sesuai dengan usia anak (bergambar dan berwarna tidak terlalu tebal)

4. Menyediakan kaset VCD dengan tema yang dekat dengan anak seperti dunia binatang, aku dan keluargaku, makanan kesukaanku

5. Memfasilitasi anak untuk belajar sesuai tahap perkembangan atau kemampuannya, tidak memaksa anak dan tidak memberikan tekanan pada anak-anak saat proses belajar mengajar berlangsung

1. Anak membuat daftar kata atau koleksi kata pada buku alphabetnya

2. Menstimulasi anak mengeluarkan ide atau pendapatnya setiap saat ketika ada suatu permasalahan atau tema tertentu

3. Memberikan kesempatan kepada setiap anak untuk berbagi pengalaman dengan teman-temannya, dengan bercerita, demonstrasi/eksperimen sederhana

4. Setelah belajar atau menggunakan media (alat-alat permainan) anak dilatih dan dibimbing untuk merapikan kembali atau meletakan kembali mainan atau buku pada tempatnya.

5. Anak mendemontrasikan hasil tulisan yang ia buat dan menempelkannya di papan buletin

6. Anak membaca buku cerita sesuai dengan pilihannya dan meletakkan kembali di rak buku

1. Guru melibatkan semua anak dalam proses belajar

2. Merencanakan kegiatan kerja kelompok dan kegiatan dirancang dengan melibatkan fisik, emosi, dan pikiran anak

3. Anak menuliskan dan menceritakan kembali cerita yang disukainya

4. Anak bercerita dengan gaya bahasanya sendiri, dengan mimik dan gerakan tubuh yang dibuatnya sendiri. Guru membimbing dan mengarahkan

5. Guru dan anak melakukan demonstrasi serta eksperimen sederhana, kemudian anak menceritakan, menggambarkan, dan menulisnya

1. Memotivasi anak untuk membaca buku cerita sendiri dan menceritakan isinya

2. Merangsang anak untuk bereksperimen membuat tulisan-tulisan dan memanjang di papan buletin

3. Merangsang keberanian, rasa percaya diri siswa dalam memberikan jawaban dan merespons guru

4. Membuat lingkungan kelas yang merangsang rasa ingin tahu anak 


\section{LANJUTAN Tabel 4}

\begin{tabular}{|c|c|c|}
\hline ASPEK & INDIKATOR & AKTIVITAS \\
\hline & \multirow{7}{*}{$\begin{array}{l}\text { 7. Feedback } \\
\text { (anak menerima respon yg } \\
\text { positif dari guru) }\end{array}$} & $\begin{array}{l}\text { 5. Anak bermain kartu huruf, kartu kata dan tulisan ( mencocokkan } \\
\text { gambar dan tulisannya) }\end{array}$ \\
\hline & & $\begin{array}{l}\text { 1. Guru dan anak memberikan respon positif dengan keberaniannya } \\
\text { untuk bercerita atau nuliskan kata }\end{array}$ \\
\hline & & 2. Berdiskusi/mengadakan rapat kecil dengan anak \\
\hline & & $\begin{array}{l}\text { 3. Membacakan biografi penulis buku cerita yang anak sukai dan } \\
\text { memberikan puijian atau tepuk tangan untuk penulis tersebut }\end{array}$ \\
\hline & & $\begin{array}{l}\text { 4. Anak dilatih memberikan komentar atau pendapat tentang buku } \\
\text { cerita yang dibaca atau penulisnya }\end{array}$ \\
\hline & & 5. Guru meminimalisir respon negatif terhadap anak \\
\hline & & $\begin{array}{l}\text { 6. Anak dilatih untuk memelihara buku-buku cerita agar terhindar dari } \\
\text { kerusakan }\end{array}$ \\
\hline
\end{tabular}

Analisis data kuantitatif yang digunakan dalam penelitian ini adalah analisis statistik deskriptif, (Arikunto, 2010: 282) yaitu mencari persentase dan nilai rata-rata peningkatan kemampuan membaca permulaan anak dan mendeskripsikan persentase data hasil penghitungan kemampuan membaca permulaan peneliti dan dua kolaborator pada setiap siklus. Adapun analisis kualitatif, peneliti merangkum, menganalisis, dan menginterpretasikan hasil temuan lapangan yang berupa catatan lapangan, hasil penghitungan kemampuan membaca permulaan dan ditunjang dengan dokumentasi yaitu foto-foto kegiatan. Persentase pada penelitian ini dihitung untuk melihat perbedaan kemampuan membaca sebelum tindakan dan setelah tindakan diberikan.

\section{HASIL DAN PEMBAHASAN}

Setelah dilakukan berbagai kegiatan pada siklus I, diperoleh hasil observasi kemampuan membaca permulaan. Hasil observasi tersebut kemudian dianalisis menguji hipotesis tindakan untuk melihat pengaruh pemberian tindakan berupa pembelajaran whole language terhadap kemampuan berbahasa, khususnya kemampuan membaca permulaan.

Pengujian hipotesis tindakan dengan menggunakan perhitungan persentase kemampuan dan persentase peningkatan pada siklus I. Berdasarkan analisis data dengan menggunakan persentase, diperoleh bahwa terdapat peningkatan kemampuan membaca permulaan setelah dilakukan tindakan pada siklus I dibandingkan dengan persentase pra-penelitian.

Persentase kemampuan membaca permulaan anak setelah dilakukan tindakan pada siklus sebesar $85.50 \%$. Persentase kemampuan membaca permulaan anak berdasarkan hasil observasi pra-penelitian sebesar $30.25 \%$, sehingga dapat disimpulkan bahwa persentase peningkatan telah mencapai hasil yang diinginkan melebihi persentase keberhasilan yaitu sebanyak minimal 20\%. Persentase peningkatan dari pra-penelitian ke siklus I sebesar $55.25 \%$, sebagaimana yang terlihat pada Tabel 5 berikut.

Berdasarkan data pada tabel 5, terlihat kemampuan membaca permulaan anak setelah diberikan tindakan mengalami peningkatan yang cukup besar dari hasil observasi pra-penelitian bahkan mencapai lebih dari 50\%. Hal ini terjadi karena dalam pembelajaran membaca permulaan di kelompok B dilakukan dengan memperhatikan prinsip-prinsip pembeljaran whole language . 
Tabel 5. Hasil Analisa Data Pra-Penelitian Dan Siklus I

\begin{tabular}{lccccc}
\hline \multirow{2}{*}{ Responden } & \multicolumn{2}{c}{ Pra Siklus } & \multicolumn{2}{c}{ Hasil Siklus I } & Peningkatan \\
\cline { 2 - 6 } & Skor & $\%$ & Skor & $\%$ & X2 - X1 \\
\hline A & 12 & 30.00 & 32 & 80.00 & 50.00 \\
B & 12 & 30.00 & 35 & 87.50 & 57.50 \\
C & 11 & 27.50 & 30 & 75.00 & 47.50 \\
D & 11 & 27.50 & 34 & 85.00 & 57.50 \\
E & 11 & 27.50 & 34 & 85.00 & 57.50 \\
F & 16 & 40.00 & 39 & 97.50 & 57.50 \\
G & 10 & 25.00 & 33 & 82.50 & 57.50 \\
H & 16 & 40.00 & 39 & 97.50 & 57.50 \\
I & 11 & 27.50 & 31 & 77.50 & 50.00 \\
J & 11 & 27.50 & 35 & 87.50 & 60.00 \\
\hline Jumlah & 121 & 302.50 & 342 & 855.00 & 552.50 \\
\hline Rata-rata & 12.1 & $30.25 \%$ & 34.2 & $85.50 \%$ & $55.25 \%$ \\
\hline
\end{tabular}

Pembelajaran membaca permulaan sebelum dilakukan tindakan menggunakan metode pembelajaran yang bersifat skolastik.., dimana anak dihadapkan pada suasana sekolah yang penuh dengan ketegangan, kegiatan anak-anak sehari-hari adalah mengerjakan lembar kerja berupa majalah dan buku paket yang diulang-ulang sehingga membosankan dan tidak jarang anak tidak mau mengerjakan tugas karena merasa tidak mampu. Kegiatan pembelajaran cenderung berpusat pada guru sehingga proses pembelajaran seperti ini tidak bermakna bagi anak, bahkan pembelajaran hanya fokus pada pengembangan kemampuan membaca, menulis, dan berhitung saja. Kemampuan lainnya hampir bahkan tidak terstimulasi.

Kegiatan simbol-simbol grafis (huruf atau kata) tidak menggunakan media kartu huruf atau kartu kata, tetapi guru menulis beberapa kata di papan tulis kemudian anak dituntun untuk mengeja dan membaca kata tersebut. Guru meminta anak satu-satu maju ke depan untuk membaca kata setelah selesai guru memberi tugas kepada anak untuk menyalin kata yang tertulis di papan tulis pada buku tulis anak. Kegiatan seperti ini setiap hari dilakukan pada anak sehingga kadang-kadang banyak anak yang mengeluh, dan tidak mau menyelesaikan tugas dengan alasan tidak bisa. Untuk kegiatan pengenalan kata atau tulisan biasanya dilakukan dengan cara anak mengerjakan lembar kerja pada buku paket atau majalah. Pada lembar kerja tersedia atau kata dengan titik-titik sehingga tugas anak adalah menebalkan titik-titik tersebut pada kolom yang tersedia kemudian meniru huruf dan kata di baris berikutnya dengan jumlah baris 5-6 baris. Selain itu anak diajarkan menulis huruf sambung.

Kondisi kelas berbeda jauh situasinya dengan ketika peneliti dan dua orang kolaborator melakukan kegiatan pembelajaran dengan menggunakan pendekatan whole language. Lingkungan kelas di-setting penuh dengan bahan bacaan dan tulisan memberikan label pada benda-benda yang ada di dalam kelas dan disediakan area baca yang penuh dengan buku cerita anak-anak. Hal ini sesuai dengan prinsip immertion. Setiap hari anak berada pada lingkungan yang merangsang anak untuk membaca, bahkan setiap pagi sebelum memulai kegiatan pembelajaran anak-anak diajak berjalan melihat, mengamati dan membaca setiap kata yang ditempel pada benda-benda di dalam kelas untuk mengaitkan anak antara konsep dengan lambang yang mewakilinya. Sebelumnya benda-benda yang ada di dalam kelas tidak diberi label dan tidak ada huruf yang ditempel serta tidak ada area baca sehingga tidak merangsang anak untuk belajar membaca.

Prinsip demonstration, guru menjadi contoh yang baik bagi anak baik dalam hal bahasa yang digunakan sehari-hari kepada anak maupun guru yang lain. Memberi contoh dalam membaca, 
kegiatan pembelajaran selalu dimulai dengan membaca buku cerita yang dipilih anak dan mengajak anak untuk membaca buku di area baca. Menstimulasi anak untuk bercerita dan mengungkapkan pendapat serta menghargai anak saat anak mengungkapkan pendapatnya dengan mendengarkan keluhan atau pendapat anak. Sebelumnya kegiatan tidak dimulai dengan membaca buku, anak-anak tidak berani mengungkapkan pendapat karena malu dan takut.

Expectation, kegiatan pembelajaran disajikan dalam suasana yang menyenangkan bagi anak, tidak ada paksaan dan tekanan pada anak serta anak belajar dengan menggunakan prinsip pembelajaran anak usia dini belajar sambil bermain dan bermain seraya belajar. Kegiatan pengenalan huruf dan kata dilakukan dengan menggunakan media yang menarik bagi anak yaitu kartu huruf, kartu kata dan kartu gambar. Mengenalkan huruf dan kata dengan bermain tebak kartu huruf, mencocokkan huruf dengan gambar menghubungkan kata dengan gambar. Sebelumnya media yang digunakan hanya lembar kerja berupa majalah dan buku paket sehingga anak merasa bosan.

Responsibility, anak-anak diajak membaca buku sendiri yang disukai di area baca ketika waktu istirahat dan waktu bermain bebas. Selanjutnya anak diajak untuk merapikan kembali buku dan alat bermain yang telah digunakan ditempatnya dengan tujuan untuk melatih rasa tanggung jawab. Anak membuat daftar kata dengan kegiatan mencari dan menggunting kata yang berawalan sama dalam katalog belanja dan kemasan makanan. Sebelumnya tidak ada kesempatan untuk membaca buku cerita karena tidak tersedia di kelas dan alat bermain yang anak gunakan. Biasanya guru yang merapikannya setelah anak-anak pulang, sehingga tidak ada rasa tanggung jawab pada diri anak.

Employment, guru selalu melibatkan anak dalam setiap kegiatan dari awal sampai akhir kegiatan. Kegiatan pemberian label pada benda-benda yang ada di kelas, anak terlibat sepenuhnya dengan menempel kata pada benda dan tentunya dengan bimbingan guru. Bahkan ketika guru menyiapkan media pembelajaran yang akan digunakan, anak diajak untuk menyiapkannya. Hal ini berbeda situasinya dengan sebelumnya dimana semua media yang akan digunakan, guru yang menyiapkan dan menyimpannya sehingga anak-anak hanya duduk manis dan mengikuti instruksi guru.

Approximation, memberikan stimulasi untuk aktivitas bereksperimen menggabungkan huruf menjadi suku kata, menggabungkan suku kata menjadi kata membuat tulisan dan mencoba membaca buku sendiri sehingga menimbulkan rasa percaya diri pada anak. Sebelumnya kegiatan yang biasa dilakukan anak pada lembar kerja adalah mewarnai, menulis, dan menghitung, sehingga anak kurang bereksplorasi.

Feedback, guru selalu memberi respon dan reward yang positif pada anak ketika anak bertanya, mengungkapkan pendapatnya dan ketika anak berhasil menyelesaikan tugas atau mampu menjawab pertanyaan guru sehingga memberi motivasi anak untuk terus belajar.

Berdasarkan hasil analisis data kuantitatif dengan menghitung persentase peningkatan kemampuan membaca permulaan, diketahui bahwa hasil observasi kemampuan membaca permulaan setelah dilakukan tindakan pada siklus I mengalami peningkatan. Data hasil observasi pra-penelitian menunjukkan bahwa skor maksimum yang diperoleh anak sebesar 16 dengan persentase sebesar 40\% dan skor minimum yang diperoleh anak sebesar 10 dengan persentase $25 \%$. Hasil akhir perhitungan persentase rata-rata dari 10 orang anak sebesar $30,25 \%$. Data hasil observasi pada siklus I menunjukkan bahwa skor maksimum sebesar 39 dengan persentase sebesar $97,50 \%$ dan skor minimum yang diperoleh anak sebesar 30 dengan persentase $70 \%$. Hasil akhir perhitungan rata-rata sebesar $85,50 \%$. Berdasarkan data tersebut, diketahui bahwa persentase 
kemampuan membaca permulaan pada siklus I lebih besar dibandingkan dengan persentase peningkatan sebesar 55,25\%. Hasil tersebut menunjukan kesesuaian dengan tindakan.

Hasil analisis kualitatif membuktikan bahwa pemberian tindakan berupa pendekatan pembelajaran whole language dengan menekankan prinsip pembelajaran yang bermakna dan menyeluruh, menyediakan lingkungan yang kaya akan literatur atau bahan bacaan dapat membantu meningkatkan kemampuan membaca permulaan anak, baik dari segi kemampuan mengenali tulisan, membaca kata dengan bunyi huruf yang benar, maupun membaca buku cerita. Dengan kegiatan bercerita, bermain, membaca, dan menulis yang sesungguhnya, menenggelamkan anak pada lingkungan yang kaya akan tulisan dan pembelajaran yang menyeluruh, sehingga kemampuan membaca dapat ditingkatkan.

Kemampuan menafsirkan simbol huruf atau kata (decoding) atau menafsirkan simbol dengan kegiatan pengenalan simbol huruf dan kata anak terlihat antusias dan mengikuti kegiatan sampai selesai. Kegiatan pengenalan huruf dan kata dengan menggunakan media kartu huruf, kartu kata, dan kartu gambar. Pengenalan huruf melalui nyanyian, bermain tebak huruf, mencari dan mengamati huruf yang menempel di dinding dan membaca buku cerita tentang huruf. Kegiatan pengenalan huruf dimulai dengan mengenalkan huruf vokal dengan menghubungkannya dengan benda-benda yang ada di dalam kelas dan gambar buah-buahan sesuai dengan tema tanaman. Pengenalan kata dilakukan dengan kegiatan mencari kata dalam katalog belanja dan kemasan makanan serta kegiatan membaca beberapa kata sederhana pada buku cerita dengan pengucapan bunyi yang benar.

Kemampuan mensejajarkan simbol huruf atau kata (analogi) kegiatannya berupa menghubungkan kata dengan gambar yang sesuai, mencocokkan huruf dengan gambar atau kata, mencari gambar yang huruf awalnya sama dan mencari sebanyak-banyaknya kata yang berawalan sama. Semua anak terlibat aktif dalam semua kegiatan tersebut. Penggunaan media yang menarik dan variatif mendukung kegiatan dan minat anak untuk mengikuti kegiatan juga sangat tinggi terbukti bahwa anak terlihat gembira dan antusias mengikuti kegiatan. Hal ini terlihat ketika anak ditugaskan untuk membawa benda mulai dari dadu, duku, dompet, daun, dahan, dodol, donat, dll, dari 20 anak hanya 4 anak yang tidak sesuai bendanya yaitu ada yang membawa apel, jeruk, anggur, dan jambu.

Kegiatan menafsirkan simbol huruf atau kata (prediction) dilakukan dengan kegiatan menggabungkan huruf menjadi suku kata, menggabungkan suku kata menjadi kata, membuat kata dari suku kata, mencari sebanyak-banyaknya kata yang diawali dengan suku kata yang sama dan kegiatan membaca kata tidak hanya gambar. Guru membimbing anak dalam kegiatan menggabungkan huruf menjadi suku kata dan menggabungkan suku kata menjadi kata yang bermakna. Semua anak diberikan kesempatan untuk mencoba sendiri dengan menggunakan media kartu huruf, kartu suku kata dan kartu gambar. Kegiatan ini diikuti anak dengan antusias, semua anak berebut ingin mencoba dan kegiatan ini dilakukan berulang-ulang hingga anak memahami.

Dengan demikian prinsip-prinsip pembelajaran whole language, yaitu immertion, responsibility, demonstration, expectation, employment, approximation, dan feedback, apabila dikembangkan dan diperdalam dapat menjadi acuan dalam merancang kegiatan pembelajaran bahasa, khususnya pembelajaran kemampuan membaca.

Berdasarkan penerapan prinsip-prinsip whole language, kegiatan pembelajaran dilakukan dengan kegiatan yang menyenangkan bagi anak dan tidak melupakan prinsip pembelajaran anak usia dini. Kegiatan membaca buku cerita secara berulang-ulang akan menambah pengetahuan anak tentang simbol-simbol huruf, walaupun tahap awal anak hanya membaca gambar. Namun seiring gambar dengan pengalaman dan stimulasi yang anak-anak p-eroleh maka akan mulai berkembang 
pemahaman dan akan menyadari bahwa yang dibaca adalah tulisan. Kegiatan mencocokkan huruf dengan gambar atau mencocokkan kata dengan gambar akan menambah pengalaman anak tentang konsep hubungan simbol dengan bunyi.

Membaca permulaan merupakan tahapan proses belajar membaca bagi anak. Anak belajar untuk memperoleh kemampuan dan menguasai tekhnik-tekhnik membaca dan menangkap isi bacaan dengan baik. Pembelajaran bahasa bertujuan meningkatkan kemampuan siswa berkomunikasi secara efektif, baik lisan maupun tulisan. Kemampuan membaca sebagai salah satu kemampuan berbahasa tulis yang bersifat resiftif perlu dimiliki agar mampu berkomunikasi secara tertulis. Pelaksanan membaca permulaan dapat dilakukan dalam dua tahap. Pertama, periode membaca tanpa buku dan periode dengan menggunakan media atau alat peraga misalnya kartu huruf, kartu kata, kartu gambar atau benda-benda yang berawalan huruf yang sama.Kedua, pembelajaran dengan menggunakan buku merupakan kegiatan membaca dengan menggunakan buku sebagai bahan pelajaran. Meningkatkan kemampuan membaca permulaan pada anak sebaiknya menggunakan strategi atau pendekatan yang dapat mempermudah anak dalam kegiatan membaca dengan mudah dan tepat serta sesuai dengan kemampuan dan tahapan perkembangan anak.

\section{KESIMPULAN}

Berdasarkan hasil penelitian, peneliti dapat menyimpulkan bahwa implementasi model pendekatan whole language ternyata dapat meningkatkan kemampuan membaca awal anak usia dini. Hal ini terbukti dari peningkatan setiap siklus yang cukup signifikan melalui penerapan pendekatan whole language dengan tahapan-tahapan tindakan kelas mulai perencanaan kegiatan, pelaksanaan, observasi hingga refleksi. Berdasarkan observasi pada pra siklus (pra penelitian) di mana pada awalnya persentase kemampuan membaca permulaan anak masih sebesar $30.25 \%$. Pada siklus I setelah dilakukan tindakan sebanyak 7 kali pertemuan diperoleh peningkatan persentase menjadi sebesar $85.50 \%$. Berdasarkan data tersebut menunjukkan peningkatan persentase kemampuan membaca awal dari hasil observasi pra siklus sebesar $55.25 \%$.

\section{SARAN}

yakni:

Ada beberapa saran peneliti terhadap unsur-unsur yang terkait dengan topik penelitian ini

1. Bagi Lembaga Pendidikan Anak Usia Dini; diharapkan dapat mengimplementasikan pendekatan pembelajaran whole language dengan prinsip-prinsipnya untuk mengembangkan kemampuan membaca permulaan, bahkan lebih jauh lagi dalam mengembangkan kemampuan berbahasa anak secara integrasi sehingga kemampuan berbahasa anak dapat berkembang. Pihak lembaga juga diharapkan senantiasa menyediakan berbagai literatur atau bahan bacaan, media yang lebih menarik dan variatif, untuk anak agar anak dapat berinteraksi secara intens dengan tulisan.

2. Bagi Guru: sangat penting bagi guru untuk memiliki kompetensi dan keterampilan dalam mengimplementasikan model pembelajaran untuk pengembangan kemampuan membaca permulaan bagi anak usia dini. Melalui pendekatan pembelajaran whole language dilakukan untuk menstimulasi minat anak untuk membaca karena dengan berinteraksi langsung setiap hari 
dengan bahan bacaan dan lingkungan yang kaya akan tulisan, memungkinkan anak untuk belajar membaca dengan memahami tulisan secara alamiah dan menyenangkan. Oleh karena itu guru diharapkan mampu memfasilitasi anak dengan menerapkan prinsip pendekatan pembelajaran whole language.

3. Orang tua dan masyarakat juga tidak bisa lepas dari perannya sebagai fasilitator dalam pengembangan kemampuan membaca permulaan anak. Orang tua dan masyarakat dapat memberikan sarana dan dukungan anak untuk membaca dimanapun dan kapanpun. Pola pengasuhan orang tua juga mempengaruhi pengembangan kemampuan membaca permulaan anak. Orang tua diharapkan menyediakan lingkungan yang kaya akan tulisan, menyediakan buku-buku cerita dan bahan bacaan lainnya, menjadi teladan dan contoh yang baik bagi anak, serta mendampingi anak dalam kegiatan belajar membaca sekaligus mengkondisikan suasana menyenangkan, agar anak menghubungkan proses membaca dengan kenyamanan emosional.

4. Peneliti selanjutnya hendaknya dapat mengembangkan penelitian lanjutan yang berkaitan dengan pengembangan kemampuan membaca permulaan anak dan pendekatan whole language dengan memasukkan aspek-aspek yang belum peneliti lakukan serta tidak menutup kemungkinan mengkombinasikannya dengan aspek atau domain lain.

\section{REFERENSI}

Anderson, R. C., et.al. (1985). Becoming a nation of readers, the report of the commision of reading. Washington: The National Institute of Education.

Arikunto, S. (2006). Penelitian tindakan kelas. Jakarta: Bumi Aksara.

Departemen Pendidikan Nasional. (2009). Menu pembelajaran generik anak usia dini. Jakarta: Departemen Pendidikan Nasional.

Dhelo, S. and Eisele, B. (2001). Managing the whole language classroom, a complete teaching resource guide. Creative Teaching Press, Cypress.

Goodman, K. (2006). What's whole in whole language? Richmond Hill. Ontario: Heinemann, Portsmouth.

Hairuddin, dkk. (2007). Pembelajaran Bahasa Indonesia. Jakarta: Direktorat Jenderal Pendidikan Tinggi Departemen Pendidikan Nasional.

Mills, G. E. (2003). Action research: guide for the teacher researcher. New Jersey: Second Edition Pearson Education.

Mulyasa, E. (2009). Menjadi guru profesional menciptakan pembelajaran kreatif dan menyenangkan. Bandung: Remaja Rosada Karya.

Morrow, L. M. (1993). Literacy development in the early years, helping children read and write. Boston: Allyn and Bacon.

Weaver, C. (2003). Understanding whole language, from priciples to practice. Michigan: Irwin Publishing.

Woolfolk, A. (2009). Educational psychology, edition x active learning edition. New York: Prentice Hall.

Yarmi, G. (2008). Pendekatan dan strategi pembelajaran bahasa dan sastra indonesia di SD. Jurnal Pendidikan Penabur No.11/Tahun ke-7/Des 2008.

Yeager, D. C. (1999). The Whole Language Companion, A Guide to Planning Personalizing and Implementating The Whole Language Classroom. Illinois: Scott Foresman and Company 